\title{
EFFECT OF ONION (Allium cepa) ADDITIVES ON GROWTH PERFORMANCE, NUTRIENTS UTILIZATION AND BLOOD PARAMETERS OF MONO SEX NILE TILAPIA (Oreochromis niloticus) FRY
}

\author{
N.F. Abdel-Hakim ${ }^{1}$, M.M.A. Lashin ${ }^{1}$, Kh. F. El-Kholy ${ }^{2}$, A.A., Al-Azab ${ }^{1}$ \\ and A.M.A.A., Zaid \\ 1- Animal Production Department, Faculty of Agriculture, Al-Azhar University, \\ Cairo, Egypt, 2- Animal Production Research Institute, Agricultural Research \\ Center, Ministry of Agriculture and Land Reclamation, Dokki, Giza, Egypt
}

\section{SUMMARY}

The present study was carried out to determine the effect of onion (Allium cepa) additives at 3 and $5 \mathrm{~g} / \mathrm{kg}$ diet either in fresh and dried forms on growth performance, nutrients utilization, carcass composition and blood parameters of mono sex Nile tilapia (Oreochromis niloticus) fry with initial weight of $0.26 \mathrm{~g}$. The treatments were performed for 22 weeks in triplicates concrete ponds sized $3 \mathrm{~m}^{3}$ stocked with 60 Nile tilapia fry for each replicate. The obtained results indicated that incorporation of dried onion in the diets improved growth performance parameters, nutrients utilization, increased protein content of whole fish body and decreased its fat content. Some blood serum parameters were affected with addition of dried onion such as increased total protein, total albumin and total globulin. The increases in these parameters were more pronounced at higher incorporation levels either in fresh or dried form of onion compared to the unsupplemented diet. The reduction in gain costs in the onion added groups was more pronounced in groups fed on diet containing dried onion at level of $5 \mathrm{~g} / \mathrm{kg}$. Based on results of the present study, addition of growing Nile tilapia diets with dried onion at $5 \mathrm{~g} / \mathrm{kg}$ diet level is recommended to achieve better growth performance, feed utilization and to reduce the costs of production of one $\mathrm{kg} / \mathrm{gain}$ in weight.

Keywords: Onion, Allium cepa, Nile tilapia, growth performance, nutrients utilization, carcass composition, blood parameters, costs

\section{INTRODUCTION}

Aquaculture and fisheries in Egypt are an important component of the agriculture sector and a significant source of animal protein. It accounts for $3.9 \%$ of agricultural production and $14.1 \%$ of total livestock and poultry production by value (FAO, 1994), whereas, it accounted for about $48 \%$ by quantity of total aquaculture production from Africa (FAO, 1996).

In Egypt, the total fish production was accounted 1067630 metric tons from all resources (GAFRD, 2008). The fish production from aquaculture activities represented about $65 \%$, while $35 \%$ of the total production was captured from fisheries. On the other hand, the total Egyptian national production of tilapia species

Issued by The Egyptian Society of Animal Production 
was 477459 tons, where 86186 tons $(80 \%)$ was obtained from aquaculture activities (GAFRD, 2008). These figures may reflect the importance of tilapia as animal protein source in Egypt. Therefore, the activity of aquaculture requires high quality feeds which should contain not only necessary nutrients but also complementary feed additives to keep organism's healthy, favor growth and environment-friendly aquaculture.

Recently, the fish feed industry exposed to increasing consumer pressure to reduce the use of antibiotics as growth promoters in fish diets, therefore, the feed producer has to find alternative feed additives. Herbs and some spices could be used as alternatives to antibiotics in fish nutrition due to their antimicrobial and growth promoting properties (Harris et al., 2001). Adding spices and medicinal herbs such as garlic, onion, marjoram, caraway, basil, anise, fennel, licorice, black seeds and fenugreek to fish diets resulted in improvement of protein digestibility and energy retention (Sakr, 2003 and El-Dakar et al., 2004 a,b) and enhancement in growth and feed conversion (Abd El-Monem et al., 2002; Shalaby et al., 2003 and El-Dakar et al., 2004a, b; Shalaby, 2004).

Onion (Allium cepa) is recognized as important medicinal plant which has a wide spectrum of actions; not only as antibacterial, antiviral, antifungal and antiprotozoal, but also has beneficial effects on the cardiovascular and immune systems (Harris et $a l ., 2001)$. It is reported to have hypoglycemic, hypolipidemic actions (Hassanein and Al-Salahy, 2000 and Slowing et al., 2001) and contains many organic disulfides and sulfoxides (Lukes, 1971).

The present study was carried out to determine the effect of onion (Allium cepa) additives in fresh and dried forms on growth performance, nutrients utilization, carcass composition and blood parameters of mono sex Nile tilapia (Oreochromis niloticus) fry reared in concrete ponds under the Egyptian conditions.

\section{MATERIALS AND METHODS}

The present study was carried out at Water Resources Research Station belonging to the National Institute of Oceanography and Fisheries at Baltim region, Kafr ElSheikh Governorate, Egypt. The experiment was lasted for 22 weeks.

\section{Feed additives preparation:}

Onion (Allium cepa) was used in two forms fresh and dried. Prior to the experiment start, fresh onion was peeled and divided into two portions. The first portion was crushed by electrical grinder, frozen and stored in poly ethylene jar until mixing of the experimental diets. The second part was cut into small slices and dried in an air for five days. The dried material was grinded in electric mill then stored in poly ethylene jar until composition of the experimental diets.

\section{Diets formulation:}

The experiment included five treatments. The first was the control diet (C) which contained $33 \% \mathrm{CP}$ and $4845 \mathrm{Kcal} \mathrm{GE} / \mathrm{Kg}$, while the other treatments were fed on control diet added with fresh and dried onion at levels of 5 and $3 \mathrm{~g} / \mathrm{kg}$ diet $\left(\mathrm{FO}_{5}\right.$, $\mathrm{FO}_{3}, \mathrm{DO}_{5}$ and $\mathrm{DO}_{3}$ ), respectively. The formulation and composition of the control diet is presented in Table (1). 
Table 1. Formulation and proximate composition (DM basis) of the control diet fed to Nile tilapia (Oreochromis niloticus) FRY

\begin{tabular}{lc}
\hline Ingredient & \% \\
\hline Fish meal $(72 \%)$ & 25 \\
Yellow corn & 30 \\
Soybean meal $(44 \%)$ & 25 \\
Rice bran & 12 \\
Vegetable oil & 6 \\
Vit. \&Min. premix * & 2 \\
Total & $\mathbf{1 0 0}$ \\
Chemical composition $(\%)$ & \\
Moisture & 8.54 \\
crude protein & 32.96 \\
crude fat & 11.13 \\
crude fiber & 2.91 \\
Ash & 7.64 \\
NFE** & 45.36 \\
GE Kcal/Kg $* * *$ & 4845 \\
\hline
\end{tabular}

* Contains per kg: vitamin A, 4.8 m. I.U; vit D3 , 0.8 m.I.U; vit E, 4.0 g; vit. K, 0.8 g; vit B1, 0.49 , vit. B2, 1.6 g; vit. B6, 0.6 g; vit. B12, 4 mg; Pantothenic acid, 4 g; Nicotinc acid, 8 g; Folic acid, $400 \mathrm{mg}$; Biotin, $20 \mathrm{mg}$; Choline chloride, $200 \mathrm{mg}$; Copper, $4.0 \mathrm{~g}$; Iodine, $0.4 \mathrm{~g}$; Iron, $12 \mathrm{mg}$; Manganese, $22 \mathrm{~g}$; Zinc, $22 \mathrm{~g}$ and Selenium $0.04 \mathrm{~g}$.

** Calculated by difference.

*** Gross energy was calculated from their chemical composition using the factors 5.65, 9.45, 4.0 and $4.0(\mathrm{Cal} / \mathrm{g} \mathrm{DM})$ for crude protein, ether extract, crud fiber and nitrogen free extract, respectively (Jobling, 1983).

\section{Experimental fish:}

Apparently healthy mono sex Nile tilapia (Oreochromis niloticus) fry were purchased from a commercial private fish hatchery located at Kafr El-Sheikh Governorate. Fish were acclimated to the experimental conditions for 7 days before starting the experiment in four fiberglass tanks $\left(1 \mathrm{~m}^{3}\right.$ each) with small aeration pump. The fish were acclimatized to the experimental condition two weeks prior to the experiment started. The fish were randomly distributed into five experimental dietary groups. The initial weight of the experimental fish was $0.26 \mathrm{~g}$.

\section{Experimental ponds and stoking rate:}

Four rectangular cement ponds were used in the present experiment with dimensions of $7.5 \times 2.25$ and 1.1 meter depth for each pond. The experimental ponds before being stocked with fish were completely drained, bottoms were exposed to sun solar for one week and treated with potassium permanganate. All ponds were divided into four partitions with sheet of screen with fine mesh size. Every partition (replicate) volume was about $3 \mathrm{~m}^{3}$. The ponds were then filled with fresh water to 70 $\mathrm{cm}$ height from underground well by electrical pump. The dietary five treatments were randomly distributed to have three replicates for each. The total number of stocked tilapia fry per replicate was 60 fry.

\section{Water quality:}

During the experimental period; water was changed and daily renewed at a rate of $20 \%$ of the water column to obtain a suitable water quality. 
Water quality parameters were measured: daily temperature $\left(24.5\right.$ to $\left.31.5^{\circ} \mathrm{C}\right)$, dissolved oxygen (DO) $(6.3$ and $9 \mathrm{mg} / 1)$, every two days ammonia $\left(\mathrm{NH}_{3}\right)(0.021$ to $0.039 \mathrm{mg} / 1), \mathrm{pH}(7.5$ to 7.9$)$, weekly water transparency $(32$ to $55 \mathrm{~cm})$, and total dissolved salts (T.D.S) (8080 and $9310 \mathrm{mg} / 1)$. All tested water quality parameters were within the optimal levels required for growth and development of Nile tilapia. Analytical methods were performed according to American Public Health Association (APHA, 1992). The $\mathrm{pH}$ and water temperature values were determined by digital temperature and $\mathrm{pH}$ meter (Orion model 720A, S/No 13062). Dissolved oxygen was monitored by using Oxygen meter (Jan way model 9071).

\section{Feeding rate:}

The experimental diets were fed on fine powder at first period until the fry reached over $1 \mathrm{~g}$. Thereafter, the fish were fed on pellets $(1 \mathrm{~mm})$ during the rest of experimental period. During the feeding practice, the fish were fed the experimental diets at rates of $30,10,6$ and $4 \%$ of their body weight for fish weights $(0-1 \mathrm{~g}),(1-$ $5 \mathrm{~g}),(5-20 \mathrm{~g})$ and $(20 \mathrm{~g}$ until end of experiment), respectively. The daily feed amount was distributed daily by hand in four equal portions at 9, 11, 13 and $15 \mathrm{hrs}$ according to Kubaryk (1980).

\section{Analytical methods:}

Initial body composition of fish was analyzed from samples of 40 fish which were frozen $\left(\right.$ at $-20^{\circ} \mathrm{C}$ ) prior to the study. At the end of the study, all fish from each replicate were harvested, their total weights $(\mathrm{g})$ were recorded and frozen for final whole body chemical analysis, five fish each replicate (15 fish each treatment).

The chemical analysis of the feed ingredients, the experimental diets and fish carcass were done to estimate moisture, crude protein $(\mathrm{CP} \%)$, ether extract (EE \%), crude fiber ( $\mathrm{CF} \%$ ) and ash contents according to the methods of AOAC (2000), while nitrogen free extract (NFE \%) was calculated by difference. Gross energy (Kcal/ Kg) contents of all the samples were calculated according to Jobling (1983).

\section{Blood serum analysis:}

At the end of the experimental period approximately $2 \mathrm{ml}$ blood sample were collected from the different groups via the caudal vein to determine of serum total protein (Henry, 1964), serum total albumin (Doumas and Biggs, 1972), serum total globulin (Coles, 1974) and serum total lipids (Knight et al., 1972).

\section{Economical evaluation:}

The economical evaluation for the experimental treatments was done to determine the cost of feed required to produce one $\mathrm{Kg}$ gain in fish weight. The cost of the experimental diets has been done in L.E. for market prices at the period of implemented experiment.

\section{Statistical analysis:}

Collected data were subjected to statistical analysis as one-way analysis of variance (ANOVA) using the general liner model procedure of SPSS (1998). Duncan's Multiple Range Test (Duncan, 1955) was used to separate means when the dietary treatment effect was significance. 


\section{RESULTS AND DISCUSSION}

The statistical evaluation of results in Table (2) indicated that fish groups $\mathrm{FO}_{3}$ and $\mathrm{DO}_{3}$ had significantly $(\mathrm{P}<0.05)$ higher final weights, weight gain and average daily gain compared to the control group, however differences among $\mathrm{FO}_{3}, \mathrm{DO}_{3}, \mathrm{DO}_{5}$ and $\mathrm{FO}_{5}$ were insignificant. The differences among the last two groups and the control group in same parameters were insignificant $(\mathrm{P}>0.05)$. Averages of specific growth rate $(\mathrm{SGR})$ indicate that group $\mathrm{FO}_{3}$ had significantly $(\mathrm{P}<0.05)$ higher value compared to the control group, however differences among the $\mathrm{C}$ group and other groups were insignificant $(\mathrm{P}>0.05)$.

Table 2. Growth performance of Nile tilapia (Oreochromis niloticus) FRY fed the experimental diets (mean $\pm \mathrm{SE})^{1}$

\begin{tabular}{|c|c|c|c|c|c|}
\hline \multirow[b]{2}{*}{ Items } & \multirow[b]{2}{*}{$\begin{array}{c}\text { Control } \\
\mathrm{C}\end{array}$} & \multicolumn{2}{|c|}{ Fresh Onion } & \multicolumn{2}{|c|}{ Dried Onion } \\
\hline & & $\mathrm{FO}_{5}$ & $\mathrm{FO}_{3}$ & $\mathrm{DO}_{5}$ & $\mathrm{DO}_{3}$ \\
\hline IW (g/fish) & $\begin{array}{c}\mathbf{0 . 2 6} \\
\pm 0.00\end{array}$ & $\begin{array}{c}\mathbf{0 . 2 6} \\
\pm 0.00\end{array}$ & $\begin{array}{c}\mathbf{0 . 2 6} \\
\pm 0.00\end{array}$ & $\begin{array}{c}\mathbf{0 . 2 6} \\
\pm 0.00\end{array}$ & $\begin{array}{c}\mathbf{0 . 2 6} \\
\pm 0.00\end{array}$ \\
\hline FW (g/fish) & $\begin{array}{c}\mathbf{8 0 . 3 5}^{\mathbf{b}} \\
\pm 0.89\end{array}$ & $\begin{array}{c}\mathbf{8 3 . 0 1}^{\mathbf{a b}} \\
\pm 0.91\end{array}$ & $\begin{array}{c}\mathbf{8 5 . 5 1}^{\mathbf{a}} \\
\pm 0.96\end{array}$ & $\begin{array}{c}\mathbf{8 2 . 5 5}^{\mathbf{a b}} \\
\pm 1.09\end{array}$ & $\begin{array}{c}\mathbf{8 4 . 0 1}^{\mathrm{a}} \\
\pm 1.21\end{array}$ \\
\hline WG (g/fish) & $\begin{array}{c}\mathbf{8 0 . 0 9}^{\mathbf{b}} \\
\pm 0.89\end{array}$ & $\begin{array}{c}\mathbf{8 2 . 7 5}^{\mathbf{a b}} \\
\pm 0.91\end{array}$ & $\begin{array}{c}\mathbf{8 5 . 2 5}^{\mathbf{a}} \\
\pm 0.96\end{array}$ & $\begin{array}{c}\mathbf{8 2 . 2 9}^{\mathbf{a b}} \\
\pm 1.09\end{array}$ & $\begin{array}{c}\mathbf{8 3 . 7 5}^{\mathbf{a}} \\
\pm 1.21\end{array}$ \\
\hline ADG (g/fish/day) & $\begin{array}{l}\mathbf{0 . 5 2} \mathbf{b}^{\mathbf{b}} \\
\pm 0.01\end{array}$ & $\begin{array}{c}\mathbf{0 . 5 4}{ }^{\mathbf{a b}} \\
\pm 0.01\end{array}$ & $\begin{array}{l}\mathbf{0 . 5 5} \\
\pm 0.01\end{array}$ & $\begin{array}{c}\mathbf{0 . 5 3}^{\mathbf{a b}} \\
\pm 0.01\end{array}$ & $\begin{array}{l}\mathbf{0 . 5 4} 4^{\mathbf{a}} \\
\pm 0.01\end{array}$ \\
\hline SGR (\%/day) & $\begin{array}{l}\mathbf{3 . 7 2}^{\mathbf{b}} \\
\pm 0.01\end{array}$ & $\begin{array}{l}\mathbf{3 . 7 4}^{\text {ab }} \\
\pm 0.01\end{array}$ & $\begin{array}{l}3.76^{\mathbf{a}} \\
\pm 0.01\end{array}$ & $\begin{array}{c}\mathbf{3 . 7 4}^{\mathbf{a b}} \\
\pm 0.01\end{array}$ & $\begin{array}{l}\mathbf{3 . 7 5}^{\mathbf{a b}} \\
\pm 0.01\end{array}$ \\
\hline $\begin{array}{l}\text { Survival Rate } \\
(\%)\end{array}$ & $\begin{array}{c}8^{85.19} \\
\pm 0.67 \\
\end{array}$ & $\begin{array}{c}91.30^{\mathbf{a}} \\
\pm 0.67\end{array}$ & $\begin{array}{c}90.00 \\
\quad \pm 1.4\end{array}$ & $\begin{array}{c}\mathbf{8 7 . 7 8} \\
\pm 0.64\end{array}$ & $\begin{array}{c}\mathbf{8 8 . 8 9}^{\text {ab }} \\
\pm 1.16\end{array}$ \\
\hline \multicolumn{6}{|c|}{$\begin{array}{l}\text { Means in the same row having different superscripts are significantly different }(\mathrm{P}<0.05) \text {. } \\
{ }^{1} \mathrm{n}=3 \text { per treatment. } \\
\text { - Weight gain }(\mathrm{WG})=\text { Final weight }(\mathrm{FW})-\text { Initial weight }(\mathrm{IW}) \text {; } \\
- \text { Average daily gain }(\mathrm{ADG})=\text { Average weight gain }(\mathrm{AWG}, \mathrm{g}) / \text { days; } \\
\text { - Specific growth rate }(\mathrm{SGR})=((\mathrm{LnFW}-\mathrm{LnIW}) / \text { feeding days }) \times 100 \text {; } \\
- \text { Survival Rate }(\%)=\text { number of fish at the end } / \text { number of fish at the beginning } \times 100\end{array}$} \\
\hline
\end{tabular}

Averages of survival rate $(\%)$ indicate that $\mathrm{FO}_{5}$ group recorded the highest survival percentage $(\mathrm{P}<0.05)$ compared to the $\mathrm{C}$ and $\mathrm{DO}_{5}$ groups, however differences among $\mathrm{FO}_{5} ; \mathrm{FO}_{3}$ and $\mathrm{DO}_{3}$ in this trait were insignificant. The superiority of growth performance parameters due to onion supplementation may attribute to the fact that onion has some essential nutrients such as vitamins, minerals amino acids and fatty acids which improve performance (Kamanna and Chandrasekhara, 1980).

Results in Table (3) show that FCR of $\mathrm{DO}_{5}$ group recorded the best (lowest) value followed in an insignificant increasing order by $\mathrm{FO}_{5}$ and $\mathrm{DO}_{3}$ groups and a significant increasing $(\mathrm{P}<0.05)$ order by FO3 and the control group, respectively. Nile tilapia diets supplemented with onion either in fresh or dried forms improved FCR and the improvement was more pronounced with dried onion at $0.5 \%$ incorporation level. 
Table 3. Feed utilization of Nile tilapia (Oreochromis niloticus) FRY fed the experimental diets $(\text { mean } \pm \mathrm{SE})^{1}$

\begin{tabular}{|c|c|c|c|c|c|}
\hline \multirow[b]{2}{*}{ Items } & \multirow[b]{2}{*}{$\begin{array}{c}\text { Control } \\
\mathrm{C}\end{array}$} & \multicolumn{2}{|c|}{ Fresh Onion } & \multicolumn{2}{|c|}{ Dried Onion } \\
\hline & & $\mathrm{FO}_{5}$ & $\mathrm{FO}_{3}$ & $\mathrm{DO}_{5}$ & $\mathrm{DO}_{3}$ \\
\hline \multirow{2}{*}{ FI (g/fish) } & $198.05^{a}$ & $193.27^{a b}$ & $202.68^{a}$ & $186.56^{b}$ & $196.21^{\mathrm{ab}}$ \\
\hline & \pm 3.50 & \pm 3.15 & \pm 3.35 & \pm 3.49 & \pm 3.25 \\
\hline \multirow{2}{*}{ FCR } & $2.47^{\mathrm{c}}$ & $2.34^{b}$ & $2.38^{b c}$ & $2.27^{\mathrm{a}}$ & $2.34^{b}$ \\
\hline & \pm 0.03 & \pm 0.01 & \pm 0.04 & \pm 0.01 & \pm 0.02 \\
\hline \multirow{2}{*}{ PER } & $1.23^{\mathrm{c}}$ & $1.30^{a b}$ & $1.28^{b}$ & $1.34^{\mathrm{a}}$ & $1.30^{a b}$ \\
\hline & \pm 0.01 & \pm 0.01 & \pm 0.02 & \pm 0.01 & \pm 0.01 \\
\hline \multirow{2}{*}{ PPV (\%) } & $20.93^{d}$ & $24.19^{a}$ & $22.59^{b}$ & $24.51^{a}$ & $21.82^{c}$ \\
\hline & \pm 0.25 & \pm 0.14 & \pm 0.36 & \pm 0.16 & \pm 0.21 \\
\hline \multirow[t]{2}{*}{ FPV (\%) } & $21.52^{b}$ & $22.47^{\mathrm{ab}}$ & $22.76^{\mathrm{ab}}$ & $23.37^{\mathrm{a}}$ & $20.43^{c}$ \\
\hline & \pm 0.16 & \pm 0.23 & \pm 0.14 & \pm 0.20 & \pm 0.15 \\
\hline \multirow[t]{2}{*}{ EU (\%) } & $12.70^{b}$ & $14.17^{\mathrm{a}}$ & $13.61^{\mathrm{ab}}$ & $14.47^{\mathrm{a}}$ & $12.81^{b}$ \\
\hline & \pm 0.12 & \pm 0.40 & \pm 0.10 & \pm 0.35 & \pm 0.19 \\
\hline
\end{tabular}

Means in the same row having different superscripts are significantly different $(\mathrm{P}<0.05)$.

${ }^{1} \mathrm{n}=3$ per treatment.

- Feed intake $(\mathrm{FI})=$ Total dry matter feed intake;

- Feed conversion ratio $(\mathrm{FCR})=$ Feed intake $(\mathrm{FI}) /$ weight gain $(\mathrm{WG})$;

- Protein efficiency ratio $(\mathrm{PER})=$ Weight gain $(\mathrm{WG}) /$ protein intake;

- Protein productive value $(\mathrm{PPV})=($ Retained protein $/$ protein intake $) \times 100$;

- Fat productive value $(\mathrm{FPV})=($ Retained fat $/$ fat intake $) \times 100$;

- Energy utilization $(\mathrm{EU})=($ Retained energy /energy intake $) \times 100$

Averages of PER for fish group fed diet $\mathrm{DO}_{5}$ recorded the highest value followed in an insignificant decreasing order by $\mathrm{FO}_{5}$ and $\mathrm{DO}_{3}$. but significant $(\mathrm{P}<0.05)$ decreasing order by $\mathrm{FO}_{3}$ and the control group, respectively. These results indicate in general that incorporation onion either in dried or fresh forms improved the PER of Nile tilapia and the improvement was more pronounced with dried onion at $5 \mathrm{~g} / \mathrm{kg}$ level.

The results of Tables ( 2 and 3 ) are in complete agreement with the findings of ElSaidy (1999) who reported that incorporation of dried onion in diets of Nile tilapia fingerlings with initial weight of $8.9 \mathrm{~g}$ at levels of 2, 4, 6 and $8 \%$ significantly improved final weights; weight gain, SGR, FCR and PER parameters compared to the unsupplemented control group. The improvement in growth performance parameters was more pronounced at $6 \%$ incorporation rate. He also added that no mortalities were detected among the treated groups.

In the present experiment, the better FCR records and PER values (Table 3) may lead to believe that some of the components in onion may contribute to better utilization of nutrients in ration. In this connection Jones and Mann (1963) reported that antibacterial compounds existing in onion may contribute indirectly towards improved nutrient utilization.

Averages of PPV values presented in Table (3) show that fish groups fed diets $\mathrm{FO}_{5}$ and $\mathrm{DO}_{5}$ showed the best PPV values $(\mathrm{P}<0.05)$ followed in a significant decreasing order by $\mathrm{FO}_{3}, \mathrm{DO}_{3}$ and the control group, respectively. 
Results of whole fish body chemical composition (Table 4) revealed that differences in DM contents of whole fish bodies among the dietary treatments were insignificant. Averages of protein content indicate that the $\mathrm{FO}_{5}$ had significantly $(\mathrm{P}<0.05)$ higher protein contents compared to the control group, however differences among the $\mathrm{C}$ group and $\mathrm{FO}_{3} ; \mathrm{DO}_{5}$; and $\mathrm{DO}_{3}$ in this trait were insignificant. The obtained results may be explained by the findings of Osman et al. (1997) who showed that dried onion has a significant effect on glycen reserve and ATPase activity in breast muscles after $24 \mathrm{hr}$ of slaughtering. Also, it improves the keeping quality of breast muscle and this improvement is increased with increasing the level of onion in the diet.

Table 4. Whole body composition (\%DM) of Nile tilapia (Oreochromis niloticus) fed the experimental diets at the end of experiment* $(\text { mean } \pm \mathrm{SE})^{1}$

\begin{tabular}{|c|c|c|c|c|c|}
\hline \multirow[b]{2}{*}{ Items } & \multirow[b]{2}{*}{$\begin{array}{c}\text { Control } \\
\mathrm{C}\end{array}$} & \multicolumn{2}{|c|}{ Fresh Onion } & \multicolumn{2}{|c|}{ Dried Onion } \\
\hline & & $\mathrm{FO}_{5}$ & $\mathrm{FO}_{3}$ & $\mathrm{DO}_{5}$ & $\mathrm{DO}_{3}$ \\
\hline \multirow{2}{*}{ DM } & 27.95 & 29.57 & 28.75 & 29.41 & 27.42 \\
\hline & \pm 1.08 & \pm 0.41 & \pm 0.69 & \pm 0.25 & \pm 0.40 \\
\hline \multirow{2}{*}{$\mathbf{C P}$} & $61.03^{b}$ & $62.95^{a}$ & $61.57^{a b}$ & $62.25^{\mathrm{ab}}$ & $61.46^{a b}$ \\
\hline & \pm 0.37 & \pm 0.47 & \pm 0.74 & \pm 0.24 & \pm 0.32 \\
\hline $\mathbf{E E}$ & $\begin{array}{l}\mathbf{2 1 . 1 1}^{\mathrm{a}} \\
\pm 0.52\end{array}$ & $\begin{array}{c}\mathbf{1 9 . 6 8}^{\mathbf{a b}} \\
\pm 0.26\end{array}$ & $\begin{array}{c}\mathbf{2 0 . 8 6}^{\mathbf{a b}} \\
\pm 0.58\end{array}$ & $\begin{array}{c}\mathbf{1 9 . 9 6}^{\mathbf{a b}} \\
\pm 0.37\end{array}$ & $\begin{array}{c}\mathbf{1 9 . 3 6}^{\mathbf{b}} \\
\pm 0.53\end{array}$ \\
\hline \multirow{2}{*}{ Ash } & $14.86^{b}$ & $14.17^{b}$ & $14.77^{b}$ & $14.89^{b}$ & $16.86^{\mathrm{a}}$ \\
\hline & \pm 0.22 & \pm 0.28 & \pm 0.57 & \pm 0.44 & \pm 0.39 \\
\hline GE & $5443^{a}$ & $5416^{a b}$ & $5450^{a}$ & $5403^{b}$ & $5302^{c}$ \\
\hline (Kcal GE/kg) & \pm 64.52 & \pm 55.34 & \pm 67.20 & \pm 48.76 & \pm 86.37 \\
\hline
\end{tabular}

On the other hand, the control group recorded the highest fat contents $(21.11 \%)$ and the $\mathrm{DO}_{3}$ group recorded the lowest $(\mathrm{P}<0.05)$ value of whole body fat contents; however differences in fat contents among the onion supplemented groups were insignificant. It is clarified that onion has been considered to effectively prevent the increase in lipid levels in experimental animal (Kumar and Berwal, 1999). Ash contents revealed that the $\mathrm{DO}_{3}$ group recorded significantly $(\mathrm{P}<0.05)$ the highest value compared to the other treatment groups. Moreover, the current results are in accordance with the findings of El-Saidy (1999) who reported that incorporation of dried onion in growing Nile tilapia diets at $6 \%$ level had insignificant effects on flesh and whole fish body moisture contents, however it increased the protein contents in the DM and decreased the fat contents compared to the control group. The same author added that onion at $6 \%$ level increased ash contents in flesh and whole fish bodies compared to the control group. Furthermore, he attributed the decrease in whole fish body fat contents to sulfur containing compounds of onion which oxidize thiol compounds present either free or combined in a protein which are necessary for lipid synthesis (Sebastian et al., 1979). 
Averages of some blood serum parameters are presented in Table (5). In general, the results revealed that incorporation of onion increased serum total protein (TP), total albumin (TA) and total globulin (TG) of Nile tilapia compared to the control unsupplemented group. The increase in these parameters were more pronounced at higher incorporation levels either in fresh or dried forms of onion. In this connection Al-Salahy (2002) reported that oral administration, one dose or one dose every 24 hours for 5 days of onion juice, to African catfish decreased significantly total serum protein after 5 hours. After repeated administration for 5 days, onion juice had no significant $(\mathrm{P}>0.05)$ effect on total serum protein. No significant $(\mathrm{P}>0.05)$ effect on serum albumen after 5 hours of administration was detected, while this single dose increased significantly serum albumen after 24 hours of administration.

Table 5. Blood serum analysis of Nile tilapia (Oreochromis niloticus) fed the experimental diets (mean $\pm \mathrm{SE})^{1}$

\begin{tabular}{|c|c|c|c|c|c|}
\hline \multirow[b]{2}{*}{ Items } & \multirow[b]{2}{*}{$\begin{array}{c}\text { Control } \\
\mathrm{C}\end{array}$} & \multicolumn{2}{|c|}{ Fresh Onion } & \multicolumn{2}{|c|}{ Dried Onion } \\
\hline & & $\mathrm{FO}_{5}$ & $\mathrm{FO}_{3}$ & $\mathrm{DO}_{5}$ & $\mathrm{DO}_{3}$ \\
\hline Total Protein & $3.18^{d}$ & $3.36^{b}$ & $3.27^{c}$ & $3.81^{a}$ & $3.27^{\mathrm{c}}$ \\
\hline g/dl & \pm 0.02 & \pm 0.01 & \pm 0.02 & \pm 0.02 & \pm 0.01 \\
\hline Total Albumin & $1.15^{c}$ & $1.42^{\mathrm{a}}$ & $1.29^{b}$ & $1.41^{\mathrm{a}}$ & $1.41^{\mathrm{a}}$ \\
\hline g/dl & \pm 0.01 & \pm 0.02 & \pm 0.02 & \pm 0.01 & \pm 0.01 \\
\hline Total Globulin & $1.55^{\mathrm{e}}$ & $1.92^{\mathrm{c}}$ & $1.98^{b}$ & $2.41^{a}$ & $1.86^{d}$ \\
\hline g/dl & \pm 0.02 & \pm 0.01 & \pm 0.01 & \pm 0.01 & \pm 0.01 \\
\hline $\mathrm{A} / \mathrm{G}$ ratio & $\begin{array}{l}\mathbf{0 . 7 4}{ }^{\mathbf{a}} \\
\pm 0.01\end{array}$ & $\begin{array}{l}\mathbf{0 . 7 4}{ }^{\mathbf{a}} \\
\pm 0.01\end{array}$ & $\begin{array}{l}\mathbf{0 . 6 5} \\
\pm 0.01\end{array}$ & $\begin{array}{c}\mathbf{0 . 5 9} \\
\pm 0\end{array}$ & $\begin{array}{l}\mathbf{0 . 7 6}^{\mathbf{a}} \\
\pm 0.01\end{array}$ \\
\hline Total Lipids g/dl & $\begin{array}{c}\mathbf{1 0 . 0 2}^{\mathbf{a}} \\
\pm 0.01\end{array}$ & $\begin{array}{c}\mathbf{8 . 9 0}^{\mathrm{d}} \\
\pm 0.02\end{array}$ & $\begin{array}{l}\mathbf{9 . 6 2} \mathbf{b}^{\mathbf{b}} \\
\pm 0.01\end{array}$ & $\begin{array}{l}\mathbf{8 . 1 9}^{\mathbf{e}} \\
\pm 0.02\end{array}$ & $\begin{array}{l}\mathbf{8 . 9 8}^{\mathbf{c}} \\
\pm 0.03\end{array}$ \\
\hline
\end{tabular}

Means in the same row having different superscripts are significantly different $(\mathrm{P}<0.05)$.

${ }^{1} \mathrm{n}=3$ per treatment.

Results of Table (5) indicated that incorporation of fresh or dried onion significantly $(\mathrm{P}<0.05)$ depressed serum total lipids and the depression was more pronounced at higher onion incorporation levels. Results of the present experiment are in accordance with the findings of Al-Salahy (2002) who reported significant depression in serum total lipids of the catfish (Clarias lazera). Furthermore, Wangensteen et al. (2004) showed that addition of natural additive onion to food will increase the antioxidant content and may have potential as a natural antioxidant and thus inhibit unwanted oxidation processes. Onion contains many organic disulfides and sulfoxides (Lukes, 1971) which are responsible for inhibition of cholesterol synthesis. Reddy et al. (1993) mentioned that onion has flavonoids, such as quercetin and quercetrin, which have antioxidant and anticancer effects.

In general results of the present study indicated that supplementing Nile tilapia diets with fresh or dried onion at 5 or $3 \mathrm{~g} / \mathrm{kg}$ diet released significant $(\mathrm{P}<0.05)$ effects on the studied blood serum parameters which may due to the presence of pharmacologically active substances with anti-inflammatory effects in onion.

Feed costs (L.E.) per one $\mathrm{Kg}$ gain in weight produced by Nile tilapia fed the experimental diets are illustrated in Table (6). The results revealed that in spite of increased diet costs for the onion supplemented diets, this supplement reduced the 
costs required for production of one $\mathrm{kg}$ gain in weight of tilapia fish and the reduction was more pronounced in groups fed on diets containing dried onion at $5 \mathrm{~g} / \mathrm{kg}$ level followed by groups $\mathrm{FO}_{5} ; \mathrm{DO}_{3}$ and $\mathrm{FO}_{3}$, respectively. The reduction in gain costs in the onion supplemented groups may due mainly to the fact that onion supplementation improved fish growth and consequently total gain in weight with almost similar feed intake. These results are in accordance with the findings of Abd El-Latif et al. (2001) who reported that incorporation of onion; garlic or a mixture (1:1) of both resulted in net revenue percent of $214.56 ; 231.46$ and $220.95 \%$, respectively in Japanese quail compared to $202.21 \%$ for the control unsupplemented group.

Table 6: Feed cost (L.E) for one Kg weight gain produced by Nile tilapia (Oreochromis niloticus) fed the experimental diets.

\begin{tabular}{|c|c|c|c|c|c|}
\hline \multirow[b]{2}{*}{ Items } & \multirow[b]{2}{*}{$\begin{array}{c}\text { Control } \\
\mathrm{C}\end{array}$} & \multicolumn{2}{|c|}{ Fresh Onion } & \multicolumn{2}{|c|}{ Dried Onion } \\
\hline & & $\mathrm{FO}_{5}$ & $\mathrm{FO}_{3}$ & $\mathbf{D O}_{5}$ & $\mathbf{D O}_{3}$ \\
\hline Feed intake (g/fish) & 198.05 & 193.27 & 202.68 & 186.56 & 196.21 \\
\hline $\begin{array}{l}\text { Cost (L.E) of one } \mathrm{Kg} \text { of } \\
\text { feed }\end{array}$ & 2.40 & 2.41 & 2.40 & 2.45 & 2.43 \\
\hline Total weight gain (g/fish) & 80.09 & 82.75 & 85.25 & 82.29 & 83.75 \\
\hline Feed cost/Kg gain (L.E) & 5.94 & 5.63 & 5.71 & 5.55 & 5.69 \\
\hline $\begin{array}{l}\text { Percentage decrease in } \\
\text { feed cost to produce one } \\
\text { Kg fish gain }\end{array}$ & 100 & 94.78 & 96.13 & 93.43 & 95.79 \\
\hline
\end{tabular}

\section{CONCLUSION}

Based on results of the present study, supplementation of growing Nile tilapia diets with dried onion at $5 \mathrm{~g} / \mathrm{kg}$ diet is recommended to achieve better growth performance; feed utilization and to reduce the costs of production of one $\mathrm{kg} /$ gain in weight.

\section{REFERENCES}

Abd El-Latif S.A., F.A. Ibrahem and A.M. Elkiaty, 2001. Some productive and metabolic responses of growing Japanese quail as affected by dietary onion and garlic. Egyptian J. Nutrition and Feeds, 4 (Special Issue): 1107-1118.

Abd El-Monem A., S.M.M. Shalaby and A.Y. El-Dakar, 2002. Response of red tilapia to different levels of some medicinal plants by-products black seed and roquette seed meals. Proceedings of the First Conference of Egyptian Aquacultural Society, El-Arish, 13-15 December, pp. 247-280.

Al-Salahy M. B., 2002. Some physiological studies on the effect of onion and garlic juices on the fish, Clarias lazera. Fish Physiology and Biochemistry, 27: 129142. 
AOAC (Association of Official Analytical Chemists), 2000. Official Methods of Analysis. 17ed., Association of Official Analytical Chemists Washington, DC, USA.

APHA, 1992. Standard Methods for the Examination of Water and Waste Water. American Public Health Association. Washington, DC.

Coles E.H., 1974. Vet. Cline Path, W. B. Sounders Company, Philadelphia, London and Toronto. PP. 211-213.

Dauncan D., 1955. Multiple range and Multiple (F) tests. Biometrics, 11: 1-2.

Doumas B.T. and H.G. Biggs, 1972. Determination of serum albumin standard methods of Clinical Chemistry. Acad. Press NY, 7, 175.

El-Dakar A.Y., G.D.I. Hassanien, S.S. Gad and S.E. Sakr, 2004a. Use of medical and aromatic plants in fish diets: 1. Effect of dried marjoram leaves on performance of hybrid tilapia Oreochromis niloticus x Oreochromis auraus, fingerlings. J. Egypt. Acad. Soc. Environ. Dev. (B. Aquaculture ), 5: 67-83.

El-Dakar A.Y., G.D. I.Hassanien, S.S. Gad and S.E. Sakr, 2004b. Use of medical and aromatic plants in fish diets: 2. Effect of dried basil leaves on performance of hybrid tilapia Oreochromis niloticus $\times$ Oreochromis auraus, fingerlings. 3rd Inter. Conf. on Animal Production and Health in Semi-Arid Areas, Suez Canal University, pp. 265-277.

El-Saidy D.M.S.D., 1999. Effect of different levels of dry onion meal supplemented to the diets on growth, feed utilization and body composition of Nile tilapia, Oreochromis niloticus (Boulenger) fingerlings. Minufiya J. of Agric. Res. Vol. 24, 2 (1): 481-492.

FAO, 1994. The marketing, distribution and trade in fish in the Arab Republic of Egypt. FAO Regional Office for the Near East (RNEA). Cairo, Egypt. 46 p.

FAO, 1996. Aquaculture production statistics 1985-1994. FAO Fish. Circ. 815 Rev. 8. Rome, FAO.

GAFRD, 2008. Summary production statistics. General Authority for Fish Resources Development. Ministry of Agriculture and Land Reclamation, Cairo, Egypt.

Harris J.C., S.L. Cottrell, S. Plummer and D. Lloyd, 2001. Antimicrobial properties of Allium sativum (garlic). Applied Microbiology and Biotechnology, 57: 282286.

Hassanein A. A. and M. B. Al-Salahy, 2000. Effects of dietary onion (Allium cepa) and garlic (Allium sativum) in alloxan-diabetic mice. The second international conference on basic sciences and advanced technology. Assiut. 5-8.

Henry R.J., 1964. Clinical Chemistry, Harper and Row publishers, New York, p. 181.

Jobling M., 1983. Effect of feeding frequency on food intake and growth of Arctic charr, Salvelinus alpinus (L.). J. Fish. Biol., 23: 177-185.

Jones H. A. and L.K. Mann, 1963. Onion and their allies, in world crops, ed. Prof. N. Polunin. Interscience Puld. Ync. NY.

Knight J.A., S. Anderson and J.M. Rawle, 1972. Chemical basis of the sulfaphosphor-vanillin reaction for estimating total serum lipids. Clan, Chem., 18: 199-202.

Kubaryk J. M., 1980. Effect of diet, feeding schedule and sex on food consumption, growth and retention of protein and energy by tilapia. Ph. D. Diss. Auburn University, Auburn. AL.

Kamanna V.S. and N. Chandrasekhara, 1980. Fatty acid composition of garlic (Allium Sativum Linnaeus) lipids. Nutr. Abstr. Rev., 51:2238 (Abst.). 
Kumar M. and J.S. Berwal, 1999. Sensitivity of food pathogens to garlic (Allium sativum). 3 of Appl. Microbiol., 84: 213-215.

Lukes T.M., 1971. Thin layer chromatography of cysteine derivatives of onion flavor compounds and the lacrimatory factor. J. Fd. Sci., 36: 662-664.

Osman A.M.A., A.Gh. Galal, Kh.A. Mohamed and F.M. Ayoub, 1997. The use of onion in the diets of broiler chickens. Egyptian J. Nutrition and Feeds (Special Issue), $1: 289$.

Reddy A.S., C.V. Rao, A. Rivenson, and G. Kelloff, 1993. Chemoprevention of colon carcinogenesis by organosulfur compounds. Cancer Res., 53: 3493-3498.

Sakr S.E., 2003. Studies on the Feeding Attractants for Fish. M.Sc. Thesis, Faculty of Environmental \& Agriculture Science, Suez Canal University, El-Arish, Egypt.

Sebastian K.L., N.F. Zacharias, B. Philip and K.T. Augusti, 1979. The hypolipidemic effect of onion (Allium cepa Linn) in sucrose fed rabbits. Indian - J Physiol. Pharmacol., 23 (1): 27-30.

Shalaby S.M. M., 2004. Response of Nile tilapia, Oreochromis niloticus, fingerlings to diets supplemented with different levels of fenugreek seeds (Hulba). J. Agric. Mansoura Univ., 29: 2231-2242.

Shalaby S.M.M., A.I. Abd Elmonem, and A.Y. El-Dakar, 2003. Enhancement of growth performance, feed and nutrient utilization, of Nile tilapia, Oreochromis niloticus, using of licorice roots (Erksous) as a feed attractive. J. of the Egyptian Acad. Soc. for Environment (B. Aquaculture), 4(2): 119-142.

Slowing K., P. Ganado, M. Sanz, E. Ruiz and T. Tejerina, 2001. Study of garlic extracts and fractions on cholesterol plasma levels and vascular reactivity in cholesterol-fed rats. J. Nutr., 131: 9945-9995.

SPSS, 1998. Statistical Program for Windows XP, Ver.14, Copyright C ,SPSS Inc.

Wangensteen H.; A.B. Sanulsen and K.E. Malterud, 2004. Antioxidant activity in extracts from coriander. Food Chem., 88: 293-297. 
تأثير إضافة البصل على الأداء الإنتاجى والإستفادة من المركبات الغذائية وقياسات الدم ليرقات البلطى النيلى وحيل الجنس.

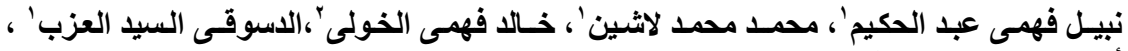
أحمد محمد عثري علي زايد اليدا،

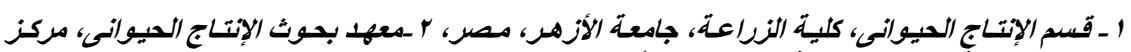
البحوث النزاعية، وزارة النزراعة وإستصلاح الأراضى، مصر.

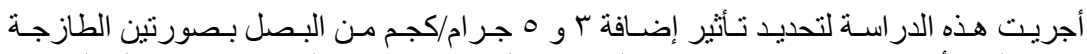

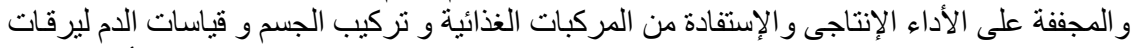

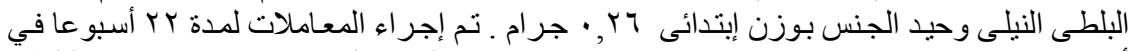

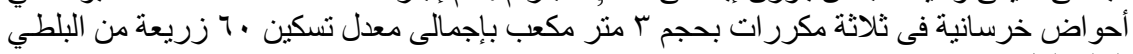

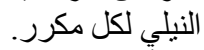

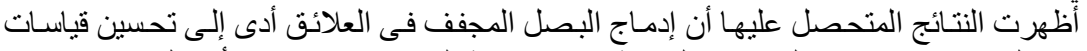

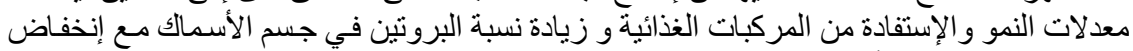

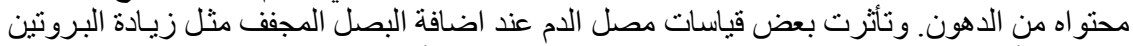

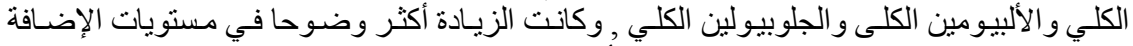

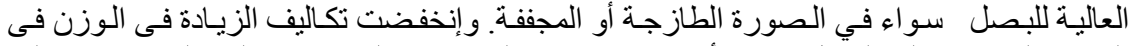

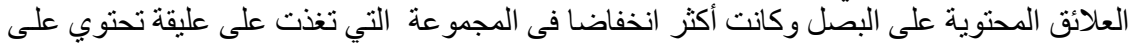

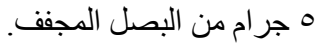

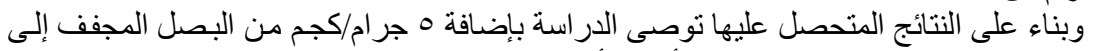
علائق البلطى النيل وحيد الجنس لتحقيق أفضل أداء إنتاجى وكفاءة غذائية وائية وكذلك لخفض تكاليف إنتاج واحد كيلو جر ام زيادة فى وزن الأسماك. 